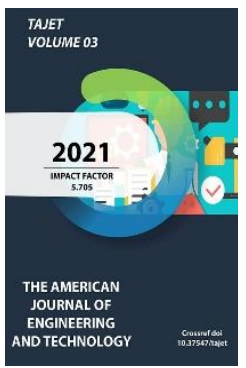

Copyright: Original content from this work may be used under the terms of the creative commons attributes 4.0 licence.

\section{Study Of The Composition Of Solutions Used In Extracts Of Local Plants And Tannins}

\author{
Abrorjon Olimjon O'g'li Xomidjonov \\ Assistant, Namangan Institute Of Engineering Technology, Uzbekistan \\ Jamshid Faxriddin O'g'li Ergashev \\ Assistant, Namangan Institute Of Engineering Technology, Uzbekistan
}

\title{
ABSTRACT
}

In this article, tannins are substances that change the physicochemical and mechanical properties of the skin when exposed to it and turn the skin into leather. Vegetable tannins are commonly referred to as tannins. Both abroad and in our country, plant extracts are mainly used to soothe thick leather on the soles of shoes, technical leather, leather of belts and seams, leather of high boots and leather.

\section{KEYWORDS}

Plants, chemical composition, tanned, vegetable raw material bark, footwear, technical leather, belt, leather, ethics, leather

\section{INTRODUCTION}

Tanned are formed as a result of plant life. A huge number of plants on the globe contain tanned in varying amounts. A plant can contain tannins in its most diverse parts: bark, wood, leaves, roots, flowers, fruit shells and the fruits themselves. 
At the same time, the chemical composition of plants of the same breed is not strictly constant and varies depending on various factors: geographical area of habitation, growing conditions, plant age, and sometimes the time of harvesting.

Despite the fact that tannids, formed in different plants, differ greatly from each other in chemical structure, they all have some common characteristics. In the molecules of all vegetable tannins there are several benzene nuclei, which necessarily contain a number of hydroxyl groups as substituents. Thus, all tannides are derivatives of polyhydric phenols, i.e. polyphenols. Concentrated tannin extracts are called herbal tanning extracts.

\section{THE MAIN FINDINGS AND RESULTS}

The extraction of tannins from tanning materials is carried out with hot water or aqueous solutions of some chemical reagents (for example, sulfurous acid salts). At the same time, in addition to tannides, other watersoluble compounds that do not have a tanning ability, which are called netannids, also pass into the solution. The ratio of the content of tannides to the total water-soluble, multiplied by $100 \%$, is called good quality. This indicator is important for determining the quality of tanning raw materials and tanning extracts.

The aqueous extracts of vegetable tanning materials have an acidic character. Their acidity is due to the phenolic hydroxyls of tannide molecules and eight free carboxyl groups of most hydrolysable tannides, as well as the presence of organic acids. For different tanning materials, the $\mathrm{pH}$ and acidity values fluctuate within the following ranges: for hydrolyzable tannides $\mathrm{pH}=3-4$, acidity $250-400 \mathrm{mEq} / \mathrm{I}$, For condensed tannides $\mathrm{pH}=4-5$, acidity 3-100 mEq II.

Tanning solutions have a significant buffering capacity, especially with respect to acids, which depends on the ratio of tannides to nontannides. Typically, the buffering capacity of high quality condensed tannide solutions is significantly lower than that of low quality hydrolysable tannide solutions. However, not only the amount of netannides, but also their different nature in individual tanning agents, as well as the actual tannins, affect the buffering capacity of various tanning extracts.

Tannids are substances with a wide range of properties, depending on their nature and partially modified as a result of certain treatments, as well as conditions of use.

Although a characteristic feature of the use of plant extracts is the availability of raw materials for industrial production, tannins are widely used throughout the world.

The use of natural tannins ensures the highest quality of leather processing. It should be noted that vegetable tanning is environmentally less hazardous than tanning with mineral salts and syntans; in addition, the use of plant extracts allows the use of leather trimmings and shavings for the production of gelatin.

The flora provides the tanning industry with a huge assortment of tanning materials that have been used for several millennia.

In the tanning-extractive industry, only wood waste is used. According to the available data, an ordinary felling area, due to the state of oak plantations, can provide an output of extracts of $30-40 \%$ [19]. An additional source of oak 
extract raw materials can be waste from furniture and other wood processing enterprises that produce products from oak wood.

The chestnut belongs to the same family as the oak, but it is faster-growing and reaches ripeness in 30-40 years. Chestnut grows in the Caucasus in the Black Sea and Abkhazian forests.
The tannicity of chestnut wood reaches 10\% (at zero moisture content and good quality 75$80 \%$ ). Chestnut extract has good tanning properties. Chestnut wood can be processed both independently and in a mixture with oak wood, increasing the tannin and good quality of oak extract.

In plants such as willow, spruce and larch, the bulk of tannins accumulates mainly in the bark.

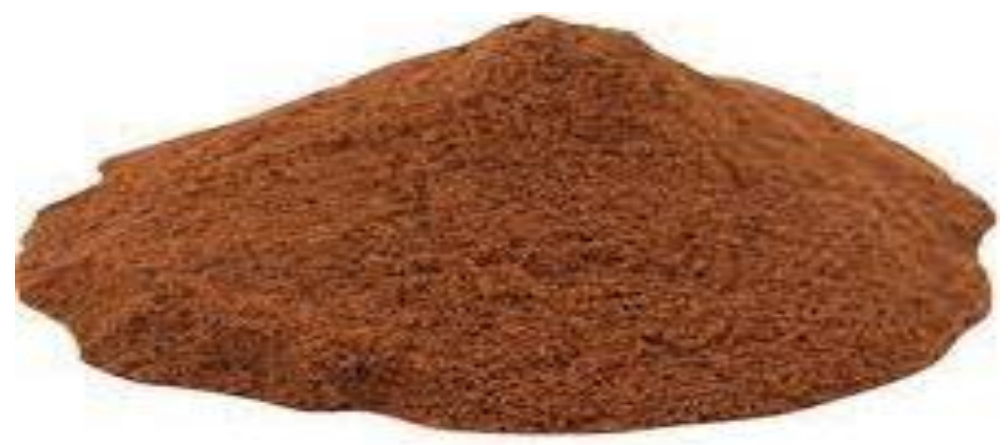

Willow grows in various places: in forests, in meadows, on the banks of rivers and lakes, and often forms solid thickets. There are over 200 species of willows and several hundred varieties of their hybrids, differing from each other in the appearance of bark, leaves, flowers, fruits, etc.

Willow bark is harvested by hand. The mechanization of blanks has not yet been carried out and is hardly possible.
The accumulation of tannins in the bark occurs with increasing age of the tree. Analyzes show that the cortical layer, depending on the age of the tree, contains $3 \cdot 5-7 \%$, and the bast layer - 7$17 \%$ of tannins. Therefore, up to $60-80$ years of age of the tree, when the cortical layer is still small, the tannins and good quality of the bark are maximum.

In addition to gallic (pyrogallic) acid, the decay products obtained during the hydrolytic cleavage of tannides also contain ellagic acid: 


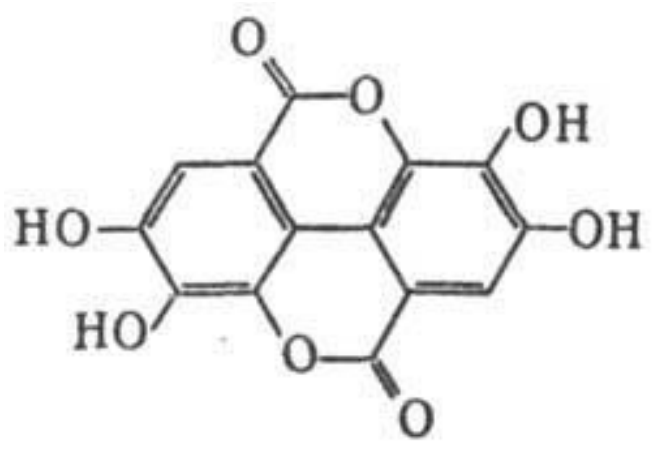

Only in 2018, a group of scientists was able to discover for the first time a plant organelle called tannosome, in which tannins - tannins are synthesized. It is formed in chloroplasts and, after the polymerization of tannins, is isolated in the membrane envelope. In this form, the tannosome moves to the vacuole, where then tannins remain.

The molecular weight of unassociated tannides ranges from 1000 to 3000 atomic units, and in associated form reaches 18,000 . The isoelectric point of most tannins is within the range of $\mathrm{pH}$ $=2.5-3.5$.

It is generally accepted that tannides in plants are formed (synthesized) from sugars through a number of intermediate products. First, phenolic substances are formed that do not have tanning properties, which, passing through a number of stages, turn into more complex compounds - tannides. As a result, the tanning complex in plants is a series of polyphenolic compounds, ranging from free phenols and their simplest derivatives to high molecular weight compounds of the tannid type, soluble and insoluble in water.

Common to all catechins is their ability, when heated in dry form and in aqueous solutions above $100^{\circ} \mathrm{C}$, as well as, when heated with acids and under the action of enzymes, they

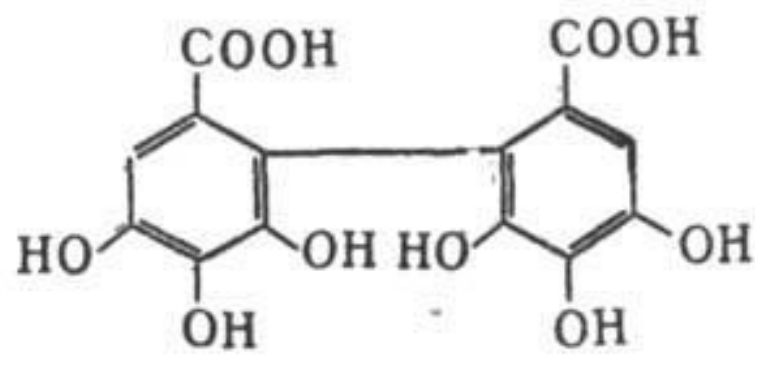

first transform into amorphous, readily watersoluble tannins, and then into red-colored water-insoluble flobaphenes. It is assumed that the formation of flobaphenes should be attributed to the pyranic ring, since it has been proven that phenolic hydroxyls do not take part in the process of flobaphenization.

Vegetable tanning materials always contain more or less various substances that pass into the water extract with tannids, the so-called netannides. Most of these various compounds belong to one of the following groups: the simplest phenols; carbohydrates and products of their polycondensation and decomposition the simplest organic acids; substances that are separated during filtration or settling of a solution of tannides, substances containing nitrogen; inorganic salts.

In tanning plants, the simplest phenols and their derivatives such as gallic acid and catechins are always present. For example, the amount of the simplest phenols, based on the mass of tannins, is: in willow bark $6-9 \%$, in oak wood $10-12 \%$, in chestnut wood $6 \%$, in quebracho wood 6-8\%. Gallic acid, based on the dry residue, contains: in chestnut wood up to $11 \%$, in oak wood $2-3 \%$, in quebracho wood $0.9 \%$, in mimosa bark $0.4 \%$. 
One of the distinguishing features of tannins is their ability to bind to collagen fibers. This ability of tannins is widely used in the tanning industry in the process of tanning pelt.

Tanning is the interaction of tanning substances penetrated into the dermis with functional groups of a protein, as a result of which cross-links are formed between adjacent chains of its structure, leading to an irreversible change in the properties of the dermis, while the skin turns into leather.

The vegetable tanning process consists of the adsorption of tannids by the dermis, diffusion of the tannids into the skin, and the binding of the tannids.

Tannids are present in the skin both in a free state and in a state bound by various forces. Depending on this, they behave differently in relation to washing out with water and alkalis.

Ultrafiltration-purified production tests of the processing properties of leather gave a positive result, on the basis of which membrane technology is used for poor-quality purification of extracts.

\section{REFERENCES}

1. Leyte $V$. Determination of organic pollution of drinking, natural and waste waters. -M .: Chemistry, 1975.-200 p.

2. Engineering, 2019, 11, 320-325 http://www.scirp.org/journal/eng ISSN Online: 1947-394X ISSN Print: 1947-3931

3. Laskov Yu.M., Fedorovskaya T.G., Zhmakov G.I. Wastewater treatment of enterprises of leather and fur industry, Moscow: Light and food industry, 1984, 198.
4. RESEARCH THE TOP AND ASATRICS MATERIALS FOR MEN SHOES Parpiev Umidjon Melievich; Ismatullaev Nizom Adashaliyevich; Khomidzhonov Frail son of Abrorjon, DOI: 10.5958/22497137.2020.00669.2 https://science.iedu.uz/index.php/archive _jspi/article/dow nload/1864/1438/5133

5. Rustamov S.M., Makhmudov F.T., Bashirova 3.3. Local sorption treatment of industrial waste water from phenol // Chemistry and technology of water. - 1994. - T. 16, No. 1. - S.69-72.

6. Create alternative methods of designing shoes enterprises / custom shoes making shoes create shoes design shoes made your own shoes. Homidjonov Abrorjon Olimjon ugli, Parpiev Umidjon Melievich, Ismatullaev Nizom Adashaliyevich JULY 2020 Page No.: 34-37 Volume-II Issue -VII PUBLISHED: $\quad 30$ JULY 2020 http://usajournalshub.com/index.php/tajii r/issue/view/116

https://doi.org/10.37547/tajiir/Volume02Iss ue07-06

7. Preis S.B., Kamenev S.B., Callas Yu.I. Oxidative treatment of phenol-containing waste water from thermal processing of shale // Chemistry and technology of water. - 1994. T. 16, No. 1, - S. 83-91.

8. Khomidjonov, A. O., Usmanov, K. H., Dadoboyev, F. M., \& Turgunov, A. N. (2020). Study and analysis of the method of gluing in the preparation of leather products. ISJ Theoretical \& Applied Science, 09 (89), 448-454. Soi: http://s-oi.org/1.1/TAS-09-89-60 Doi: https://dx.doi.org/10.15863/TAS.2020.09.8 9.60

9. Kubelka V., Binko I. Synthetic tanning agents. - M .: Gizlegprom, 1959, 160. 
10. DESIGN OF A MODERN MODEL OF BOOTS FOR BOYS 0.48047/IJIEMR/VO9//11/38 Title: DESIGN OF A MODERN MODEL OF BOOTS FOR BOYS Volume 09, Issue 11, Pages: 194-200 Paper Authors A.A. Hojiev, V.B. Babakulovna, O.B. Babakulovna, A.O. Homidjonov https://ijiemr.org/public/uploads/paper/78 8841606643605.pdf

11. Yaroshenko H.A. Influence of temperature and acidity of the medium on ultrafiltration fractionation of tanning solutions // Kozhev.- footwear, industry. 1989. No. 8. - S. 41-42.

12. Меженинов М.Ю. и др. Производство растительных дубильных экстрактов / М.Ю. Меженинов, М.Н. Красухин, Б.А. Егоров - М.: Ростехиздат, 1962. - 292 С.

13. Vegetable tanning materials // The Leather Manufacture, 1984, July, - P.18-28. 